\title{
Manajemen Asuhan Kebidanan Antenatal Care pada Ny "A" dengan Preeklamsia Ringan Sampai Nifas Hari Ke-3 di RSUD Syekh Yusuf Gowa Tahun 2019
}

\author{
${ }^{1}$ Iqrayanty, ${ }^{2}$ Anieq Mumthiah Al Kautzar, ${ }^{3}$ Ferawati Taherong
}

\begin{abstract}
ABSTRAK
Pendahuluan preeklamsia merupakan salah satu komplikasi kehamilan pada trimester II dan trimester III. Ini adalah suatu kondisi medis di mana timbul hipertensi dalam kehamilan pada usia kehamilan 20 minggu dan di temukannya protein dalam urin
\end{abstract}

Metode penelitian ini adalah studi kasus dengan pendekatan Manajemen Asuhan Kebidanan Antenatal pada Ny "A" dengan Preeklamsia Ringan sampai Nifas hari ke-3 di RSUD Syekh Yusuf Kabupaten GowaTahun 2019 sesuai Manejemen Asuhan Kebidanan7 langkah Varney dan pendokumentasian dalam bentuk SOAP.

Hasil dari studi kasus dilakukan pada Ny "A" dengan preeklamsia Ringan, tidak ditemukan hambatan pada saat penanganan kasus ini. Penanganan yang dilakukan pada Ny " $\mathrm{A}$ " yaitu dengan menganjurkan untuk memeriksakan kehamilannya setiap minggu untuk melihat kondisi ibu dan keadaan janinnya serta pemberian obat anti hipertensi yaitu obat Nefedipin $10 \mathrm{mg}$.

Kesimpulan dari kasus yaitu diantaranya pendokumentasian dalam bentuk SOAP yang digunakan untuk proses penyelesaian masalah kebidanan telah dilaksanakan pengkajian berupa pemantauan dari analisa data pada Ny "A" dengan Preeklamsia Ringan Di RSUD Syekh Yusuf Gowa Tahun 2019 selama 2 minggu dan kunjungan rumah 2 kali maka didapatkan hasil yaitu tekanan darah sudah turun menjadi $120 / 90 \mathrm{mmHg}$, proteinuria Negatif serta pembengkakan pada tungkai menurun dan kehamilan berlangsung normal keadaan janin baik dan telah dilakukan pengkajian pendokumentasian semua temuan dan tindakan yang telah dilaksanakan pada $\mathrm{Ny}$ " $\mathrm{A}$ " dengan hasil tidak ditemukannya kesenjangan antara teori dan kasus.

\author{
*UIN Alauddin Makassar \\ *iqrayanty04@gmail.com
}

\section{PENDAHULUAN}

Preeklamsia adalah sekumpulan gejala yang secara spesifik hanya muncul selama kehamilan dengan usia lebih dari 20 minggu. Penyebab preeklamsia Etiologi terjadinya preeklampsi belum bias diketahui secara pasti sampai saat ini, tetapi ada beberapa faktor yang mempengaruhi terjadinya preeklampsi yaitu primigravida/nulliparitas, usia ibu yang ekstrim (35 th), riwayat keluarga pernah preeklampsi/eklampsi, penyakit-penyakit ginjal dan 
hipertensi yang sudah ada sebelum hamil, obesitas, diabetes melitus, penyakit trofoblas $(70 \%$ terjadi pada kasus molahidatidosa). Menurut Norma (2013).

Data preeklamsi terjadi pada kehamilan pertama sebanyak 85\%.Paritas 2-3 merupakan paritas paling aman ditinjau dari kejadian preeklamsi dan risiko meningkat lagi pada grande (Novianti, 2015).Angka kematian ibu akibat preeklamsia di Indonesia adalah antara 9,8\% sampai 25\%. Kejadian preeklamsia di Indonesia di perkirakan 3,4\% sampai 8,5\%. Di Indonesia preeklamsia berat dan eklamsia merupakan penyebab kematian berkisar $15-25 \%$.

Menurut data World Health Organisation (WHO) secara keseluruhan, preeklamsia dan eklamsia terjadi kurang lebih 14\% kematian maternal per tahun yaitu sekitar 50.000-75.000 kematian.

Preeklamsia di perkirakan sebagai penyebab kematian 50.000-60.000 ibu hamil setiap tahunnya. Preeklamsia di ketahui merupakan contributor utama prematuritas. Preeklamsia merupakan sebuah sindrom sistemik dalam kehamilan yang bermula dari plasenta akibat dari invasi sitotrofoblas plasenta yang adekuat diikuti dengan disfungsi endotel maternal yang meluas. Semua gejala klinis preeklamsia disebabkan oleh endoteliosis glomerulus, peningkatan permeabilitasvaskuler, dan respon inflamasi sistemik yang menyebabkan jejas / dan atau hipoprefus ipada organ (Dumais,2016).

Survey demografi dan kesehatan Indonesia (2002-2003) angka kematian ibu adalah 307 per 100.000 kelahiran hidup. Manuaba (2007) juga menyatakan bahwa penyebab utama kematian ibu di Indonesia disamping perdarahan adalah preeklamsia dan eklamsia. Kasus preeklamsia dan eklamsia terjadipada 6-8\% wanita hamil di Indonesia (Aliyahdkk, 2015).

Hasil pengambilan data awal yang di dapatkan di Rumah Sakit Syekh Yusuf Gowa tentang jumlah Preeklamsia Ringan pada tahun 2015 sebanyak 3 kasus dan jumlah Preeklamsia berat sebanyak 37 kasus, tahun 2016 Preeklamsia ringan sebanyak 4 kasus dan jumlah Preeklamsia berat sebanyak 43 kasus, tahun 2017 Preeklamsia ringan sebanyak 4 kasus dan preeklamsia berat sebanyak 54 kasus (Data RSUD Syekh Yusuf, 2015-2017).

\section{METODE PENELITIAN}

Melaksanakan studi kasus dengan pendekatan Manajemen Asuhan Kebidanansesuai dengan 7 langkahVarney dan pendokumentasian dalam bentuk SOAP. Penatalaksanaan Asuhan dilakukan dengan pemberian asuhan yang sesuai standar operasional prosedur pada kasus yang diteliti yaitu Manajemen Asuhan Kebidanan Antenatal Care dengan Preeklamsia Ringan 


\section{HASIL PENELITIAN DAN PEMBAHASAN}

\section{Langkah I ( Pengumpulan Data Dasar )}

Pada studi kasus ini dilakukan pengkajian pada Ny "A". Dari hasil anamnesis, ibu mengatakan bahwa ia mengeluh sakit kepala, sering pusing dan pembengkakan pada kedua kaki. Ibu merasakan keluhannya semenjak 2 mniggu terakhir dan mengatakan khawatir dengan kondisinya dan kondisi janinnya.

Kunjungan pertama ibu pada tanggal 21 Februari 2019 di RSUD Syekh Yusuf Gowa, hasil pemeriksaan dengan Berat Badan ibu $75 \mathrm{~kg}$, tekanan darah 140/100 mmHg, nadi $88 \mathrm{x} /$ menit, pernafasan $22 \mathrm{x} /$ menit, suhu 36,90c. Pemeriksaan abdomen di dapatkan TFU 1 jrbpx 1 jrbpx, $27 \mathrm{~cm}$, teraba bokong sesuai usia kehamilan yaitu 35 minggu 3 hari (34-36 minggu), punggung kanan, presentase kepala, terdengar jelas dan kuat denyut jantung janin di kuadran kanan bawah perut ibu dengan frekuensi 138x/menit secara teratur, dan oedema pada kedua kaki dan keadaan janin baik dan ibu dengan preeklamsia ringan. Pemeriksaan Laboratorium didapatkan hasil Hb 11 gr\% Albumin: +1, Reduksi: Negatif (-). Pemeriksaan USG yaitu: tunggal, hidup, presentase kepala, usia kehamilan 34-36 minggu, jk:Perempuan, TBJ: 2295 gram.

Kunjungan kedua dilakukan di RSUD Syekh Yusuf Gowa, hasil pemeriksaan keadaan umum ibu baik, kesadaran komposmentis. Ibu mengeluh masih merasakan sedikit pusing dan sakit kepala. Saat dilakukan pemeriksaan tanda-tanda vital ibu didapatkan hasil Tekanan darah 140/90 $\mathrm{mmHg}$, nadi $86 \mathrm{x} /$ menit, pernafasan $20 \mathrm{x} /$ menit, suhu $36,8^{\circ} \mathrm{C}$, berat badan ibu 76 kg, pada pemeriksaan fisik terfokus didapatkan hasil tidak ada oedema pada wajah, konjungtiva merah muda dan sclera putih pada mata. Pemeriksaan abdomen didapatkan TFU 2 jrbpx $30 \mathrm{~cm}$, teraba bokong dan sesuai dengan usia kehamilan yaitu 36 minggu 3 hari (36 minggu-38 minggu) dengan presentase kepala, punggung kanan, dan bergerak di atas panggul. Denyut jantung janin terdengar kuat dan jelas di kuadran kanan bawah perut ibu dengan frekuensi 138x/menit secara teratur, dan oedema pada kedua kaki.

Kunjungan ketiga dilakukan di rumah klien di jalan dr.WahidinSudirohusodo dengan hasil pemeriksaan bahwa ibu baik, kesadaran komposmentis, berat badan ibu $77 \mathrm{~kg}$, dengan keluhan sakit kepala yang dirasakan sudah berkurang dan pusing yang dirasakan sudah hilang, kembali melakukan aktivitas seperti bisa namun tidak melakukan aktivitas berat dan 
tidurnya pada malam hari sudah nyenyak meskipun masih merasakan sakit kepala. Saat dilakukan pemeriksaan tanda-tanda vital di dapatkan hasil tekanan darah 130/90 mmHg, Nadi 86x/menit, Pernafasan 20x/menit, suhu $36^{\circ} \mathrm{C}$. hasil TFU 3 jrbpx $35 \mathrm{~cm}$, teraba bokong dengan usia kehamilan 37 minggu 3 hari (36-38 minggu), presentase kepala, punggung kanan dan bergerak diatas panggul. Denyut jantung janin terdengar kuat dan jelas di kuadran kanan bawah perut ibu dengan frekuensi 140x/menit secara teratur dan oedema pada kedua kaki.

Kunjungan keempat di lakukan di rumah klien, hasil pemeriksaan kondisi umum klien baik, kesadaran komposmentis, berat badan $77 \mathrm{~kg}$ dengan keluhan ibu mengatakan sudah tidak merasakan sakit kepala dan pusing, belum ada pengeluaran lendir dan darah dan belumada pengeluaran air. Pemeriksaan tanda-tanda vital didapatkan hasil tekanan 120/90 $\mathrm{mmHg}$, Nadi 86x/menit, pernafasan 20x/menit, suhu $36,6^{\circ} \mathrm{C}$. Pada pemeriksaan terfokus tidak terjadi oedema pada wajah, konjungtiva merah muda dan sclera putih pada mata, pembesaran perut sesuai usia kehamilan dengan TFU 3 jrbpx, $36 \mathrm{~cm}$, teraba bokong dengan gestasi 38 minggu 3 hari, presentasi kepala, punggung kanan, dan bergerak di dalam panggul dengan denyut jantung janin terdengar kuat dan jelas dikuadran kanan bawah perut ibu dengan frekuensi 140x/menit secara teratur dan masih terdapat oedema pada kedua kaki.

\section{Langkah II ( Identifikasi Diagnosa atau Masalah Aktual )}

Hasil pengkajian data subjektif dan objektif yang diperoleh menunjukkan diagnosis terjadi preeklamsia ringan pada kasus Ny"A”. Ibu datang dengan keluhan sakit kepala, sering pusing dan pembengkakan pada kedua kaki. Berdasarkan pemeriksaan fisik yang telah dilakukan pada Ny"A" ditemukan hasil bahwa tekanan darah ibu 140/100 mmHg serta pembengkakan pada kedua kaki dan pemeriksaan laboratorium ditemukan bahwa proteinuria +1 .

Berdasarkan data diatas masalah aktual ialah preeklamsia ringan. Preeklamsia dalam kehamilan adalah penyakit dengan tanda-tanda hipertensi, oedema, dan proteinuria yang timbul karena kehamilan. Penyakit ini biasanya timbul pada trimester III pada kehamilan, tetapi dapat timbul sebelumnya (Marni dkk, 2012:66).

Setelah mengetahui diagnosa ibu, segera dilakukan penanganan yang tepat dan menganjurkan suami dan keluarga ibu untuk selalu berdoa kepada Allah SWT agar 
dimudahkan dalam penyembuhan ibu. Dengan demikian dapat disimpulkan bahwa berdasarkan teori, hasil penelitian dan studi kasus tidak terdapat kesenjangan.

\section{Langkah III ( Identifikasi Diagnosa atau Masalah Potensial )}

Dampak preeklamsia ibu hamil dengan usia kehamilan diatas 20 minggu (Trimester III) atau sebelumnya dapat terjadi kelahiran prematur, resiko terjadinya Bayi Berat Lahir Rendah (BBLR), abrupsio plasenta, resiko terjadinya kematian bayi (Bothamley, Boyle, 2013:194).

Penyebab terjadinya kelahiran prematur pada ibu hamil yang mengalami preeklamsia karena pada daerah arteri spiralis yang memiliki resistensi vaskuler disebabkan oleh kegagalan invasi trofoblas ke arteri spiralis pada tahap kedua. Akibatnya, terjadi gangguan aliran darah di daerah intervisi yang menyebabkan penurunan perfusi daerah ke plasenta. Hal ini dapat menimbulkan iskemia dan hipoksia di plasenta yang berakibat terganggunya pertumbuhan bayi intrauteri (IUGR) hingga kematian bayi.

Anjurkan ibu dan keluarga untuk selalu berzikir, berdoa, mendengarkan lantunan ayat suci Al-Qur'an dan hal lain yang dapat mendekatkan diri kepada Allah SWT agar selalu diberikan kesehatan, dijauhkan dari rasa sakit sehingga tidak terjadi komplikasi yang semakin memperburuk kondisi ibu dan diberikan kesembuhan.

Dengan demikian berdasarkan hasil penelitian, penerapan teori dan manajemen asuhan kebidanan pada Ny "A" dengan studi kasus Preeklamsia Ringan belum mengalami tanda bahaya tersebut tetapi harus segera dilakukan penanganan segera mungkin untuk mencegah terjadinya komplikasi yang akan terjadi karna apabila ibu tidak mendapatkan asuhan dan penanganan sedini mungkin kemungkinan besar ibu akan mengalami komplikasi dari preeklamsia Ringan.

\section{Langkah IV (Tindakan Emergency atau Kolaborasi)}

Kunjungan pertama pada tanggal 21 Februari 2019 sampai kunjungan keempat pada tanggal 13 Maret 2019 yang dilakukan pada kasus Ny"A" didapatkan hasil pemeriksaan yang menunjukkan bahwa keadaan umum ibu baik, kesadaran komposmentis, pada saat dilakukan pemeriksaan tanda-tanda vital pada tanggal 21 Februari 2019 didapatkan hasil bahwa ibu 
mengalami preeklamsia ringan dengan tekanan darah 140/100 $\mathrm{mmHg}$, dengan proteinuria +1 , terdapat pembengkakan pada kedua kaki, ibu mengeluh sakit kepala dan sering pusing. Sedangkan pada pemeriksaan tanggal 13 Maret 2019 didapatkan hasil tekanan darah 120/90 mmHg pada kedua kaki masih ada pembengkakan pada kedua kaki, ibu sudah tidak merasakan lagi sakit kepala dan tidak merasa pusing lagi.

Namun pada pasien Ny"A" tidak diberikan tindakan segera karena tekanan darah masih dalam batas preeklamsia ringan dan tidak ada tanda-tanda terjadinya preeklamsia berat maka dianjurkan untuk melakukan kunjungan antenatal setiap minggu untuk mengantisipasi preeklamsia ringan yang dialaminya.

\section{Langkah V (Merencanakan Asuhan yang Menyeluruh)}

Rencana asuhan tindakan pada Ny "A" dengan kasus preeklamsia ringan dilakukan dengan menentukan tujuan asuhan yang akan diberikan. Tujuan penatalaksanaan tersebut yaitu agar dapat dilakukannya rencana asuhan kepada ibu agar kehamilan dapat berlangsung normal, keadaan ibu dan janin baik, dan preeklamsia ringan yang dialami dapat teratasi. Adapun kriteria keberhasilan rencana asuhan yang diberikan yaitu, kehamilan aterm (37-42 minggu), keadaan ibu baik, tanda-tanda vital normal, djj dalam batas normal, tidak ada tanda bahaya pada kehamilan, keadaan janin baik, peningkatan berat badan dalam batas normal, albumin dan oedema negatif, keluhan ibu yaitu pusing dan sakit kepala berkurang atau hilang.

Rencana tindakan yang disusun berdasarkan tujuan yang sesuai kebutuhan pasien pada Ny"A" dengan kasus preeklamsia ringan pada masa kehamilan yaitu, dilakukannya kunjungan untuk evaluasi setelah diberikan terapi rawat jalan dan pemberian obat nefedifin, memberitahu hasil pemeriksaan, pendidikan kesehatan tentang makanan yang bergizi, personal hygiene, istirahat yang cukup, mendiskusikan tentang tanda bahaya kehamilan, mendiskusikan tentang komplikasi yang dapat terjadi pada kehamilan, mendiskusikan tentang tanda-tanda preeklamsia berat, mendiskusikan tentang persiapan persalinan dan kelahiran bayinya. Rencana asuhan yang telah disusun berdasarkan diagnosa/masalah aktual dan potensial, hal ini menunjukkan tidak ada kesenjangan antara teori dengan tinjauan manajemen asuhan kebidanan pada penerapan studi kasus dilahan praktek. 


\section{Langkah VI (Implementasi)}

Pada kasus Ny "A", 35 tahun dengan diagnosa preeklamsia ringan pada masa kehamilan. Pada kasus ini, diagnosis ditegakkan berdasarkan anamnesis, pemeriksaan fisik dan pemeriksaan penunjang. Penatalaksanaan pada studi kasus Ny "A" dengan preeklamsia ringan semua tindakan yang telah direncanakan dapat dilaksanakan seluruhnya dengan baik dan tidak menemukan hambatan yang berat karenan adanya kerja sama dan penerimaan yang baik dari klien dan keluarga yang koperatif serta sarana dan fasilitas yang mendukung dalam pelaksanaan tindakan di RSUD Syekh Yusuf. Dalam tindakan asuhan kebidanan penulis tidak menemukan tindakan yang berarti karena seluruh tindakan yang dilakukan sudah berorientasi pada kebutuhan klien.

\section{Langkah VII (Evaluasi)}

Hasil evaluasi setelah melakukan asuhan kebidanan adalah sebagai berikut. Pada pelaksanaan evaluasi pada tanggal 21 Februari -26 Maret 2019 pada Ny "A" yaitu kehamilan berlangsung normal ditandai dengan keadaan umum ibu baik, kesadaran komposmentis, tekanan darah 140/100 mmHg menurun menjadi 120/80 mmHg pembesaran perut sesuai usia kehamilan dan detak jantung janin dalam batas normal. Pusing, sakit kepala, dan pembengkakan pada kedua kaki berkurang. Dengan demikian hasil asuhan kebidanan yang telah diberikan pada Ny"A" berhasil dengan melihat perubahan yang telah dirasakan ibu baik dari keluhan, tekanan darah, oedema pada kedua kaki dan kehamilan berlangsung normal.

\section{KESIMPULAN DAN SARAN}

\section{A. KESIMPULAN}

1. Pengumpulan data dasar telah dilaksanakan pada Ny"A" dengan preeklamsia ringan di RSUD Syekh Yusuf tahun 2019. Dilaksanakan dengan mengumpulkan data subjektif dan objektif yang diperoleh dari hasil wawancara dimana ibu mengatakan merasakan pusing, sakit kepala, tekanan darah diatas normal, pembengkakan pada kedua kaki dan pemeriksaan proteinuria di RSUD Syekh Yusuf Gowa pada tahun 2019.

2. Telah dilaksanakan perumusan diagnosa/masalah aktual Ny"A" dengan preeklamsia ringan di RSUD Syekh Yusuf Gowa tahin 2019 dengan mengumpulkan data seperti 
data tekanan darah, pemeriksaan fisik (oedema pada kaki atau wajah), dan pemeriksaan proteinuria sehingga didapatkan diagnosa kebidanan pada Ny"A" dengan preeklamsia ringan pada masa kehamilan.

3. Telah melakukan perumusan diagnosa/masalah potensial pada Ny"A" dengan preeklamsia ringan di RSUD Syekh Yusuf Gowa tahun 2019 yang mengantisipasi terjadinya preeklamsia berat bahkan Eklamsia yang bisa terjadi pada ibu dan mengantisipasi terjadinya Berat Badan Lahir Rendah (BBLR), gawat janin, bahkan kematian yang bisa terjadi apabila penanganan yang tepat dan cepat.

4. Telah mengidentifikasi perlunya tindakan segera pada Ny"A" dengan preeklamsia ringan di RSUD Syekh Yusuf Gowa tahun 2019 dengan hasil bahwa kasus ini tidak dilakukan tindakan kolaborasi karena tidak adanya indikasi dan data yang menunjang untuk dilakukannya tindakan tersebut.

5. Telah menetapkan rencana tindakan asuhan kebidanan pada Ny"A" dengan preeklamsia ringan di RSUD Syekh Yusuf Gowa tahun 2019, dengan hasil merencanakan asuhan berdasarkan diagnosa/masalah potensial yang dapat terjadi, serta memberikan dukungan psikologis dan spiritual kepada ibu dan keluarga agar senantiasa berdoa dan berdzikir kepada Allah SWT.

6. Telah melaksanakan tindakan asuhan yang telah direncanakan pada Ny"A" dengan preeklamsia ringan di RSUD Syekh Yusuf Gowa tahun 2019 dengan hasil yaitu semua tindakan yang telah direncanakan dapat dilaksanakan seluruhnya dengan baik tanpa adanya hambatan .

7. Mengevaluasi hasil asuhan tindakan yang telah dilaksanakan pada Ny"A" dengan preeklamsia Ringan di RSUD Syekh Yusuf Gowa pada tahun 2019 dengan hasil asuhan yaitu asuhan yang telah diberikan berhasil dengan ditandai perubahan tekanan darah dari $140 / 100 \mathrm{mmHg}$ menjadi $120 / 90 \mathrm{mmHg}$ dan proteinuria yang awalnya +1 dan akhirnya menjadi (-) dan oedema pada belum hilang namun sudah berkurang dan akan menghilang setelah beberapa minggu setelah persalinan.

\section{B. SARAN}

\section{Untuk klien}

a. Menganjurkan kepada ibu agar mengkomsumsi makanan yang bergizi dan diet makanan protein, tinggi lemak dan komsumsi garam dikurangi. 
b. Menganjurkan agar setiap ibu hamil memeriksakan kehamilannya secara dini dan teratur serta dapat mengenal tanda-tanda bahaya kehamilan.

c. Mengerti dan melaksanakan setiap anjuran dan pendidikan kesehatan yang diberikan.

2. Bagi tenaga kesehatan

a. Dalam melakukan tugas sebagai bidan untuk memberikan tindakan perlu diketahui rasional setiap tindakan yang diberikan kepada klien dan harus dengan persetujuan klien dan melakukan tindakan asuhan secara profesional baru menyerahkan hasil akhirnya kepada Allah SWT karena hidup dan matinya seseorang hanya Allah yang mengetahuinya.

b. Tenaga kesehatan khususnya bidan hendaknya senantiasa membina hubungan yang baik dengan klien dan keluarga sehingga tercapainya tujuan yang diinginkan.

c. Profesi bidan harus mampu mengambil suatu keputusan klinik untuk menghindari keterlambatan merujuk sehingga dapat mencegah kematian ibu dan bayi.

3. Bagi institusi

a. Menambah bahan bacaan di perpustakaan yang berhubungan dengan perkembangan terbaru ilmu kebidanan baik yang berasal dari dalam negeri maupun luar negeri sehingga dapat memperluas wawasan mahasiswi kebidanan UIN Alauddin Makassar.

b. Membekali mahasiswi dengan keterampilan yang cukup sebelum turun dilapangan khususnya dalam hal resusitasi karena keterampilan ini merupakan bantuan dasar kehidupan yang wajib dimiliki bagi setiap tenaga kesehatan.

4. Bagi RSUD Syekh Yusuf Gowa

a. Mensosialisasi penerapan APN terbaru dalam pemberian pelayanannya.

b. Sebaiknya pihak rumah sakit senantiasa memeriksa kelengkapan dan kelayakan alat agar selalu kondisi siap pakai

c. Adanya sosialisasi atau pelatihan bagi tenaga kesehatan mengenai penatalaksanaan resusitasi secara uptudate.

5. Bagi pemerintah

a. Sering mengadakan pelatihan demi meningkatkan pengetahuan dan kemampuan para tenaga kesehatan. 
b. Menyediakan fasilitas penentu kebijakan dalam pelayanan kesehatan yang merata yang dapat menjangkau seluruh lapisan masyarakat

\section{DAFTAR PUSTAKA}

Aliyahdkk, Evaluasi Penggunaan Obat Anti Hipertensi Pada Pasien Preeklamsia dan Eklamsia Di instalasi Rawat Inap RSUD Panembahan Senopati Bantul Yogyakarta. 2015.

Benson, Ralph C, danPernoll, Martin L. Buku Saku Obstetri dan Ginekologi. EGC Jakarta 2013.

Baung dan SeiSelincah Di Kota Palembang.JurnalKedokteran Dan Kesehatan 2016. Vol 3.No.1.

Caroline, dkk. Hubungan obesitas pada kehamilan dengan preeklamsia .Jurnal e-Clinic 2016 Vol 4, No. 1.

Dwi Widiarti dan Novi Mahendrawati. Buku Saku Asuhan Kebidanan Varney. EGC Jakarta 2010.

Estur Tiar dan Devi Yulianti. Patofisiologi dalam kehamilan.EGC Jakarta 2013.

Elizabeth Siwi Walyani. Asuhan Kebidanan Pada Kehamilan. Yogyakarta. 2013.

Ermaya, Nery dkk .Pengaruh Motivasi dan Persepsi Pelayanan Terhadap Keteraturan Antenatal Care Pada Ibu Hamil Di Puskesmas Ngemplak Simongan Kota Semarang Pada Tri Wulan I Tahun 2015. Jurnal Kesehatan Masyarakat. Vol 3.No. 3. 2015.

Fatkiyah dkk. Determinan Maternal Kejadian preeklamsia (StudiKasus DI KabupatenTegal, Jawa Tengah). Jurnal Keperawatan Soedirman. 2016. Vol 11, No. 1.

John Wantania, problems in managing eclamsia jurnal biomedik (JBM) 2017. Vol 9, No. 2.

Khuzaiyah dkk. Karakteristik Ibu Hamil Preeklamsia. Jurnal Ilmiah Kesehatan (JIK) 2016. Vol IX No 2.

Kementrian Agama RI, Al-Qur'an dan terjemahannya 2016.

Marni, dkk .Asuhan Kebidanan Patologi. Pustaka Pelajar Yogyakarta 2011.

Marniyati dkk. Pelayanan Antenatal Berkualitas Dalam meningkatkan Deteksi Resiko Tinggi Pada ibu Hamil Oleh Tenaga Kesehatan Di Puskesmas Sako, Sosial, SeiZeisler, Haral ddkk. Predictive Value of the sFlt-1:PlGF Ratio in Women with Suspected Preeklamsia. Journal of Medicine. 2016. Vol 374. No. 1.

Nugroho.Buku Ajar Obstetri Untuk Mahasiswa Kebidanan.Nuha Medika. Yogyakarta. 2014. 


\section{Jurnal Midwifery}

Nugroho.Buku Ajar Asuhan Kebidanan I (Kehamilan).Yogyakarta. 2014.

Novianti, Hinda. Pengaruh Usia dan Paritas Terhadap Kejadian Preeklampsia di RSUD Sidoarjo. 2013.

Rukiyah dan Yulianti. Asuhan Kebidanan 4 (Patologi).Trans Info Media.Jak-Tim. 2010.

Ramanda Penerapan Sistem Pakar Untuk Mendiagnosa Penyakit Pada Kehamilan. 2013.

Shihab, M.Quraish. Pesan, kesan, dan keserasian Al-Qur'an(Tafsir Al Misbah)

Sujiyatini dkk. Asuhan Patologi Kebidanan Plus Contoh Asuhan Kebidanan. NuhaMedika. Yogyakarta. 2009.

Setiawati, Dewi. Kehamilan Dan Pemeriksaan Kehamilan. Alauddin University Press. 2013.

Yuniarti dkk. Analisis Perilaku Kesehatan Dan Faktor Resiko Kejadian Preeklampsia Pada Ibu Hamil Di Poliklinik Obstetri Gynekologi RSUD Kabupaten Kediri .Journal of Issues in Midwifery. 2017.

Yanti. Konsep Dasar Asuhan Kehamilan. Refika Aditama. Bandung. 2017.

Yulianti, Devi. Kebidanan Oxford. EGC Jakarta 2011 